\title{
SYLVIA TOWNSEND WARNER'S LETTERS TO OLIVER STONOR
}

The small cache of letters recently acquired by the Society provides a fascinating insight into Warner's continuing Dorset-based political activities during a period relatively unrepresented within the Diaries and the Letters. the aftermath of the Spanish Civil War. Her visits to Spain to support the Republican cause are well-documented: in 1936 she and Ackland were attached to an ambulance unit in Barcelona in what Warner described as an 'office-boy' capacity, and in July 1937 they were delegates at the Second Congress of the International Association of Writers and Artists for the Defence of Culture (IAWDC) in Madrid and Valencia. These visits generated some of Warner's best political writing including Barcelona (p.3) and Soldiers and Sickles (p.17). She also translated Spanish romanceros for Left Review and for Spender's anthology Poems for Spain. She felt honoured by the regard of the Spanish people for les intelectuelles, observing forty years later: 'I have tried to justify that esteem ever since'. But Warner's support was not only intellectual. Back in England she raised funds for soap to send to Spanish women who had no means to wash their children or their clothes; she wrote recipes and cooked for Basque refugee children brought to Thame from Bilbao. As these letters to Oliver Stonor demonstrate, she also sought to find sympathetic English hosts for Spanish and Hungarian refugee writers, negotiating with elegant persuasiveness, wry humour, unfailing good manners and gritty determination for a humanitarian cause. Janet Machen initiated the correspondence with Stonor who was a family friend. 
19.ii.39

Dear Oliver,

I must tell you straight away that this is a begging letter. I remember how very kindly you responded to the last begging letter that I wrote to you a long while ago, and this is really the same kind of thing. I hope that you can understand the enclosed letter, I can only just. Since Barcelona has fallen of course there have been thousands of people pouring out who do not wish to stay there, and this special appeal is for the intellectuals, it is organised by Aragon who you may know of, and my cousin Sylvia asked me to do what I could to collect money. All the money that is collected is being concentrated on getting them to England, and the sooner that they can be got out the better. If you feel that you can give some money please send it straight away to Sylvia Townsend Warner, Frome Vauchurch, Maiden Newton, Dorset. I know that this is a very badly written and composed letter, I am sorry. I hope that if the same situation arises in England people will be as inclined to assist us as they are these people.

I read your book when I was last at Amersham, and was very pleased to do so. It has given us all a good deal of pleasure. Is the whole hive buzzing around your head I wonder?

I am only here for the week-end getting over a cut hand that had to be sewn together. I have a room in Regent Square which I expect you know. Daddy lived in it for some time. I live at number 29.

I hope that you are well.

Love from Janet.

\section{3.ii.39}

Dear Mr Stonor,

Thank you very much indeed for your cheque. I hope your case of conscience is solved. The Aragon Committee for getting intellectuals out of the refugee camps does actually include dealing with the International Brigade: and with the most desperately 
courageous, desperately desperate section of it: those people who escaped from Fascist countries to fight for Spain, and who are now completely at a loss where to turn, since the only thing their own countries would do for them would be to imprison or kill them.

I think you will be glad to know that your money is going to their help; and I'm sure you will be glad to know that one of them, Ludwig Renn, has reached shelter already, thanks to this same fund.

Of course I remember you - and I would like very much to meet you again. If I am further west I will let you know, on the chance of a meeting. And equally, if you come this way, you will drop me a line?

Yours sincerely

Sylvia Townsend Warner

\section{7.iii.1939}

Dear Mr Stonor,

Thank you very much for your letter. I have sent it straight on to Ivy Elstob, our secretary, asking her to note the names and do what she can. It is possible the names are already on our list - every day it grows longer and more pitiful (and more shameful) - but we do our best.

I have also written to Miss Barta, asking her to send further particulars straight to Ivy Elstob. This seems the quickest arrangement.

Yours sincerely

Sylvia Townsend Warner

22.iii.1939

Dear Mr Stonor,

Thank you very much for your letter. I have written to Mrs 
Elstob, our secretary, asking her to send you some of our circulars, which will show you the kind of thing we are trying to do, and also suggesting that she should find something for you to do right away. A helper is to be jumped at.

We are chiefly engaged, as far as the international refugee problem goes, with trying to get writers and representatives of culture out of their fixes; money is not the only thing that we need. Another thing that is terribly needed is guarantors, and offers of hospitality. Many of these are simply official. One has to have something to present to the immigration authorities.

There is also the problem of looking after the refugees who are in the country. This is the function of the Arden Society, which sets itself to supply social and professional kindnesses, ranging from the giving of English lessons to the arranging of exhibitions for artists, jobs for writers, and so forth. Their address is Stanley Richardson, Secretary, Arden Society, 14 Dulverton Mansions, Gray's Inn Road, WC1.

Stanley Richardson is a friend of mine, you might mention my name if you write to him.

Of course it is difficult to do so much when one lives in the country; but there are one or two things that only people who live in the country can do. One of them, that is always valuable, is to cover local newspapers. I don't know how it is in your part of the world. Here the local blackshirts have kept up a pretty steady campaign of letters to the local paper to the effect that refugees mean unemployment, look after our own people first, and so on. Very likely there is something of the same sort going on in Devon. It's an awful corvée to ask of any one - to read his local paper. But it can be a very useful act; and if you would study yours and fire in a letter from our side occasionally it would be really valuable, because such letters reach a public which is often inclined to sympathise with us, but seldom if ever hears our point of view.

Yours sincerely

Sylvia Townsend Warner 


\section{1.iv.1939}

\section{Dear Mr Stonor}

You will find that I am taking you at your word on this matter of helping refugees.

First, I enclose some copies of the Report of our Association Internationale des Ecrivains about the work that has already been done for the Refugees from Catalonia in the French camps, and the need - there is a great need - for more money so that we can help more. Can you possibly distribute these among people you know - if possible with a personal letter? I know this is a bore to do, on the other hand impersonal begging does nothing, and personal begging does a great deal. A friend of mine and myself have already raised over fifty pounds by this personal begging, and I have an ambition to go on to a hundred pounds if I can get more helpers.

Further, can you possibly find a host in this country for some of these refugees? I have in mind a Spanish writer and journalist with his wife. He is called Vicente Salas Vius; and he has been recommended to me by the French Committee. So far, the burden of hospitality has fallen almost entirely on France; and we are most desperately anxious to get some people moved on to this country, so that their vacated places may be filled by others out of the camps. There must be people in this country with a spare room, and enough money to feed one or two extra mouths, and enough compassion to be ready to. And as people in the country tend to have more room than London flat-dwellers it occurs to me that you might be able to find a temporary home for the Salas Vius.

As for the formalities of permit and passport, we can see to that if we are armed with the name of the person ready to receive them.

Another thing that is needed is guarantors. Very often this does not involve hospitality, all that is needed is to have the guarantee of some reputable person of British nationality. This can be particularly useful in the case of Czech refugees, who are not so destitute as the Spaniards.

You see, I really am taking you at your word. I can't tell you 
how grateful I shall be if you can help. Like you, I have suffered a good deal from people who wag their heads and say Dreadful, and Terrible, but never stir foot or hand to do anything.

Yours sincerely

Sylvia Townsend Warner

15.iv.1939

Dear Mr Stonor,

Thank you so much for your letter. I think you are being extremely good (it is a serious thought to undertake hospitality to complete strangers), and as for your questions they are most prudent and sensible.

I have forwarded them to the Committee now responsible for the Salas Vius; and will let you know their reply.

Yours sincerely

Sylvia Townsend Warner

17.iv.1939

Dear Mr Stonor,

Another refugee possibility has turned up which I think might suit you better than the Spanish couple. It's a man called Pavel Banyai. He's a Hungarian writer, was an artist first, middle-aged, German and some English. He had to get out of Hungary for political reasons, and was living in Prague while it was a city of refuge. And got caught there.

Thanks to his perfectly good Hungarian passport, perfectly good for any country except Hungary, there is a chance of him getting away. He has got as far as being put on the USA quota July 1939-40, and by a great deal of patient asking, and a prod on his behalf put in by Humbert Wolfe we have got the Home Office to say they will give him a permit to come to 
England, provided they can be assured exactly where he is going to stay while here. I can see to the actual guarantee myself, and would be able and pleased to provide part of the money for his keep; but I cannot house him myself, since I have another exile coming here tomorrow.

I think perhaps he might suit you better. For one thing, he likes living in the country, and would be adaptable. He can swim and cook, and has a book to finish, and swears he would be no trouble. I know all this because part of the official dance is a letter of invitation from this country to show as a reason for travel. His name was sent me by our Association, and since the first letter we have written several times, and so I feel I know him as a person.

As a case, I suppose he is even more deserving than the Salas Vius. For they at any rate are not in danger of their lives, and are out of their concentration camp. Whereas quite a small tilt of the balance may drop him into death or t'other thing. Here is his photograph ... which seems to me to show the face of a fellow-creature that would be not too bad as a guest. He will get off to USA as soon as he can, which helps with the very serious problem of How Long?

Yours sincerely

\section{Sylvia Townsend Warner}

I do hope you don't curse the day you wrote to me. I can assure you that I am most appreciative of your kindness.

16.v.1939

Dear Mr Stonor,

I have heard from Paris that it has been finally decided that the Salas Vius had better stay there. You see it is both difficult and expensive getting visas, permits, and so forth, and unless they were coming for a long time it might not be worth it.

Meanwhile I have been trying for all I'm worth to get Pavel Banyai over. His visa is still unsettled. He writes the most 
pathetic letters. In one he says how every evening when he goes home he finds himself beginning to pack, and packs on, in a sort of wish-fulfilment dream, or sits looking at his suitcase.

Now I have got to go to New York for a month or so, leaving all this unsettled. Mrs Elstob, the secretary of our Association knows of your offer of hospitality. I feel that we must seem to be abusing it, not to send you some one at once; but I have been holding on to Pavel Banyai because he is, in a way, particularly suitable. He wants to write, and he wants to live in the country (this last is not common).

Will you let Mrs Elstob have a line to say if you still feel prepared to have Banyai, say for a couple of months, and don't mind this continued uncertainty about when he will get over.

Better write to her private address. Mrs Ivy Elstob, 20b, Wilmington Square, London, WC1.

Alternatively, if you want some one soon, why not try the British Committee for Spanish Refugees, 69, Victoria Street, SW1. Secretary Miss Montagu Pollock.

They look after the lot that came over after the fall of the Negrin Government, mostly people from Madrid and Valencia. But I advise you to point out that you live in the country, because not all Madrilanos take kindly to green fields, as I have learned by a recent experience in this neighbourhood.

I don't think it's a horrible confession that you would prefer a good writer. I've never read a book of Banyai's. But at any rate he is not a hack writer, for he was an artist for some time, and gave up painting because he wanted to write. So at any rate he must have some vocation, and takes it seriously. He has written chiefly about Central European peasant life, and provincial life, he tells me.

We take every possible precaution that people are all right as regards spying and so forth. Heaven knows how one can tell. The H.O. sieves pretty thoroughly for that, however, and they presumably know their job.

Yours sincerely

Sylvia Townsend Warner 